The University of Maine

\title{
DigitalCommons@UMaine
}

Earth Science Faculty Scholarship

Earth Sciences

$3-1-2001$

\section{Glacial Lake Wright, a High-Level Antarctic Lake During the LGM and Early Holocene}

Brenda L. Hall

University of Maine-Main, brendah@maine.edu

George H. Denton

University of Maine - Main, gdenton@maine.edu

B. Overturf

Follow this and additional works at: https://digitalcommons.library.umaine.edu/ers_facpub Part of the Earth Sciences Commons

\section{Repository Citation}

Hall, Brenda L.; Denton, George H.; and Overturf, B., "Glacial Lake Wright, a High-Level Antarctic Lake During the LGM and Early Holocene" (2001). Earth Science Faculty Scholarship. 39.

https://digitalcommons.library.umaine.edu/ers_facpub/39 


\title{
Glacial Lake Wright, a high-level Antarctic lake during the LGM and early Holocene
}

\author{
B.L. HALL ${ }^{1,2,3}$, G.H. DENTON ${ }^{1,2}$ and B. OVERTURF ${ }^{2}$ \\ ${ }^{1}$ Department of Geological Sciences, University of Maine, Orono, ME 04469, USA \\ 'Institute for Quaternary Studies, University of Maine, Orono, ME 04469, USA \\ ${ }^{3}$ Woods Hole Oceanographic Institution, Woods Hole, MA 02543, USA
}

\begin{abstract}
We report evidence of a large proglacial lake (Glacial Lake Wright) that existed in Wright Valley in the McMurdo Dry Valleys region of Antarctica at the last glacial maximum (LGM) and in the early Holocene. At its highstands, Glacial Lake Wright would have stretched $50 \mathrm{~km}$ and covered c. $210 \mathrm{~km}^{2}$. Chronology for lake-level changes comes from 30 AMS radiocarbon dates of lacustrine algae preserved in deltas, shorelines, and glaciolacustrine deposits that extend up to $480 \mathrm{~m}$ above present-day lakes. Emerging evidence suggests that Glacial Lake Wright was only one of a series of large lakes to occupy the McMurdo Dry Valleys and the valleys fronting the Royal Society Range at the LGM. Although the cause of such high lake levels is not well understood, it is believed to relate to cool, dry conditions which produced fewer clouds, less snowfall, and greater amounts of absorbed radiation, leading to increased meltwater production.
\end{abstract}

Received 18 October 1999, accepted 15 September 2000

Key words: Antarctica, McMurdo Dry Valleys, lakes, Last Glacial Maximum

\section{Introduction}

The McMurdo Dry Valleys region of Antarctica is one of the coldest and driest environments on Earth. It is seemingly an anomaly that today in this region there are lakes with permanently unfrozen water that support life, primarily cyanobacteria and diatoms. Yet our data show that these present lakes are but small remnants of much larger lakes that existed at the last glacial maximum (LGM). Here we report evidence of an extensive proglacial lake that existed in Wright Valley, the central of the three main Dry Valleys, during the LGM and early Holocene.

Wright Valley $\left(77^{\circ} 30^{\prime} \mathrm{S}, 160-163^{\circ} \mathrm{E}\right)$ trends west to east through the Transantarctic Mountains from the East Antarctic Ice Sheet to the Ross Sea (Fig. 1). Wright Upper Glacier, a small outlet glacier draining Taylor Dome, occupies the valley head, whereas Wright Lower Glacier, a westwardflowing lobe of the coastal Wilson Piedmont Glacier, blocks the valley mouth. The valley has interior drainage. Water from Lake Brownworth, proglacial to Wright Lower Glacier, flows $27 \mathrm{~km}$ westward via the Onyx River to Lake Vanda, which occupies the central depression.

Wright Valley today contains two lakes (Brownworth and Vanda), as well as several small ponds. Lake Brownworth $\left(2 \times 10^{6} \mathrm{~m}^{2}\right)$ is proglacial to Wright Lower Glacier and overflows through the Onyx River. Lake Vanda $\left(6.7 \times 10^{6} \mathrm{~m}^{2}\right)$ is a closed-basin lake reaching a maximum depth of about $70 \mathrm{~m}$ (Chinn 1993). It is fed by meltwater from the Onyx River, $95 \%$ of which comes from Wright Lower Glacier (Chinn 1980). Although there are relict stream channels descending to Lake Vanda from both the north and south valley walls, we have never observed flow in them. Don Juan
Pond ( $3 \times 10^{4} \mathrm{~m}^{2},<1 \mathrm{~m}$ deep, Chinn 1993), a hypersaline playa, occupies an isolated basin in the South Fork of the Dais. The lake precipitates antarcticite, a variety of calcium chloride. Other small saline ponds occupy central Wright Valley and the North Fork of the Dais.

Wright Valley is a polar desert, with a mean annual temperature of $-20^{\circ} \mathrm{C}$ and less than $10 \mathrm{~mm}$ (water equivalent) of precipitation ayear at Lake Vanda (Riordan 1973, Thompson 1973). Ablation $(30-40 \mathrm{~cm}$ ) exceeds accumulation (Chinn \& McSaveney 1987), which takes place commonly by drifting of snow. Meltwater forms during a brief two-month period in the summer (December and January) when temperatures can rise to as much as $10^{\circ} \mathrm{C}$ in some interior locations. Meltwater production seems to be enhanced on cloudless, calm days when absorbed incoming radiation is most intense. The system is very sensitive to changes in radiation balance and is affected particularly by late spring/early summer snowstorms (Chinn 1979, 1981, 1993, Denton et al. 1989, Fountain et al. 1998).

\section{Evidence for the existence of Glacial Lake Wright}

Evidence for the existence of a high-level lake in Wright Valley during the LGM and early Holocene comes from morphological features, such as deltas and shorelines, as well as from glaciolacustrine sediments.

\section{Deltas}

Deltas dating to the LGM and early Holocene occur along Clark Stream and the Onyx River in eastern Wright Valley 


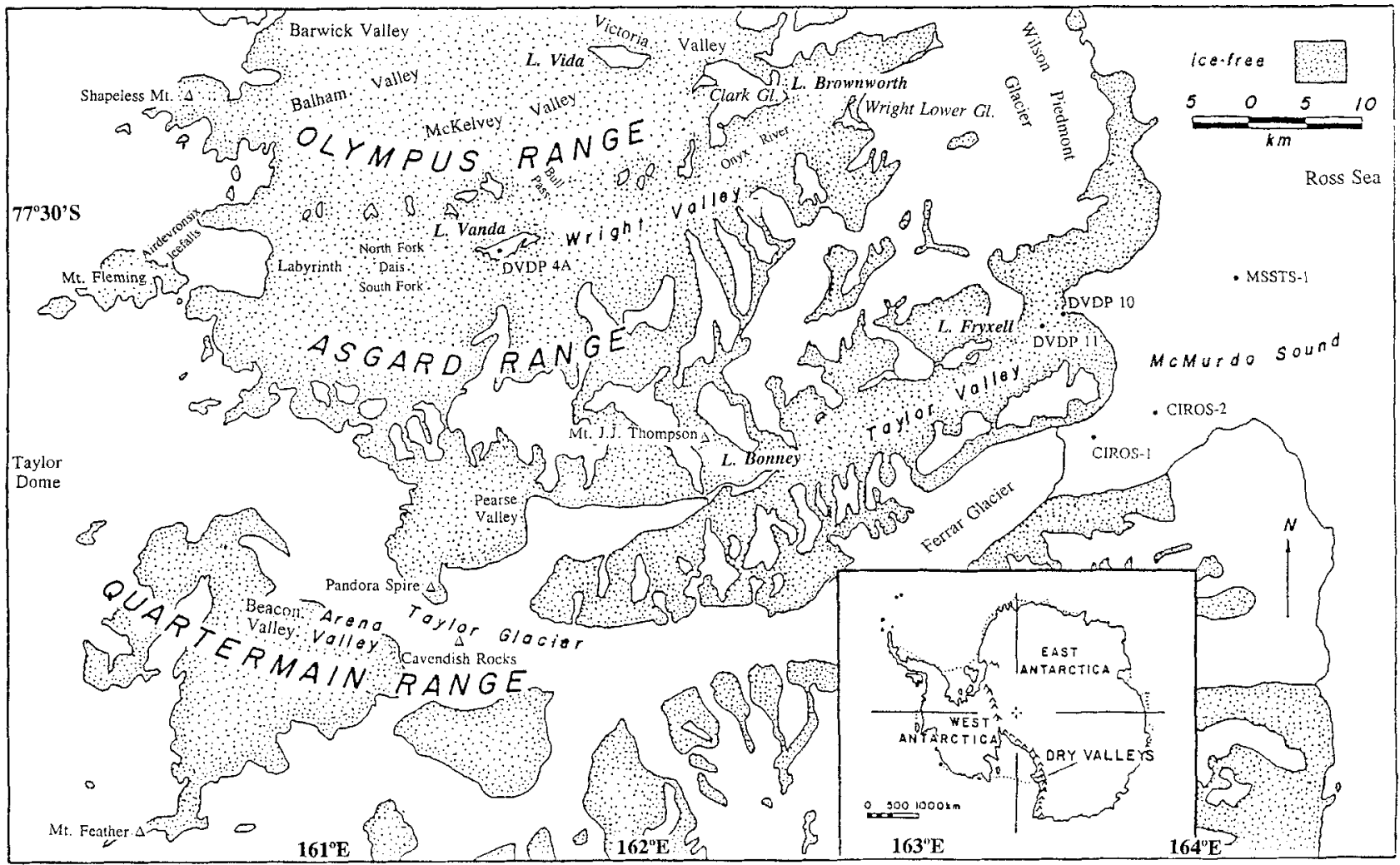

Fig. 1. Index map showing principal locations mentioned in text.

(Figs 1 \& 2). Additional deltas of mid- to late-Holocenc age exist near Lakes Brownworth and Vanda, but these will be the topic of a separate paper. The most complete set of deltas occurs along Clark Stream. Here they are preserved between 394 and 460 m elevation, relating to levels up to about $375 \mathrm{~m}$ above present-day Lake Vanda ( $85 \mathrm{~m}$ elevation). A delta also occurs along the Onyx River at about 250 m elevation. The largest two deltas are approximately $8000 \mathrm{~m}^{2} \mathrm{each}$, whereas most are less than $100 \mathrm{~m}^{2}$ (Fig. 3). Deltas have $2-20 \mathrm{~m}$ of relicf and commonly are flat-topped with steeply dipping fronts. This size and morphology are typical of deltas in the McMurdo Dry Valleys (Hall et al. 2000). All of the deltas are composed of stratified, interbedded silt and sand with less common gravel layers. Foresets occur in some deltas. Finegrained, well-sorted, slightly orange sand with abundant biotite flakes is common. Fine-grained yellow silt with climbing ripples is interbedded near the toe of some deltas. Layers of lacustrine algae occur at least rarely within all deltas and form the basis of our radiocarbon chronology (see below).

\section{Shoreline}

A prominent, well-devcloped, laterally continuous $(2.5 \mathrm{~km})$ bench occurs along the west side of Clark Valley at $566 \mathrm{~m}$ elevation (Fig. 4). This horizontal bench extends from Clark Glacier southward to the edge of Wright Valley, where it begins to curve westward around a bedrock cliff. It is consistently $3-5 \mathrm{~m}$ wide. Two sand mounds ( $1 \mathrm{~m}$ of relief) are superimposed on this otherwise flat surfacc. The bench is composed of orange-coloured, well-sorted, biotite-rich sand and silt with a fine gravel surface lag (Fig. 5). Sediments directly downslope are draped with this biotite-rich sand, whereas weathered grey till occurs upslope. Gravel clasts on the bench are well-sorted and rounded and contrast sharply with the angular clasts of the unsorted drift upslope. At the contact between the drift and the sand, angular gravel clasts arc aligned perpendicular to the bench. Layers of lacustrine algae are preserved within both the sand mounds and the bench itself. The morphology, continuity, horizontality, sedimentology, contrast with adjacent deposits, and algal content of the bench all indicate that it is a shoreline formed by a higher-than-present lake. A second, much fainter, shoreline at approximately the same elevation is etched into a fan $20 \mathrm{~km}$ to the west in Bull Pass, near Lake Vanda.

\section{Glaciolacustrine deposits}

Glaciolacustrine deposits also attest to the existence of Glacial Lake Wright. Thesc sediments occur on the valley floor and walls to an elevation of at least $386 \mathrm{~m}$, which affords a minimum estimate of former lake level. 


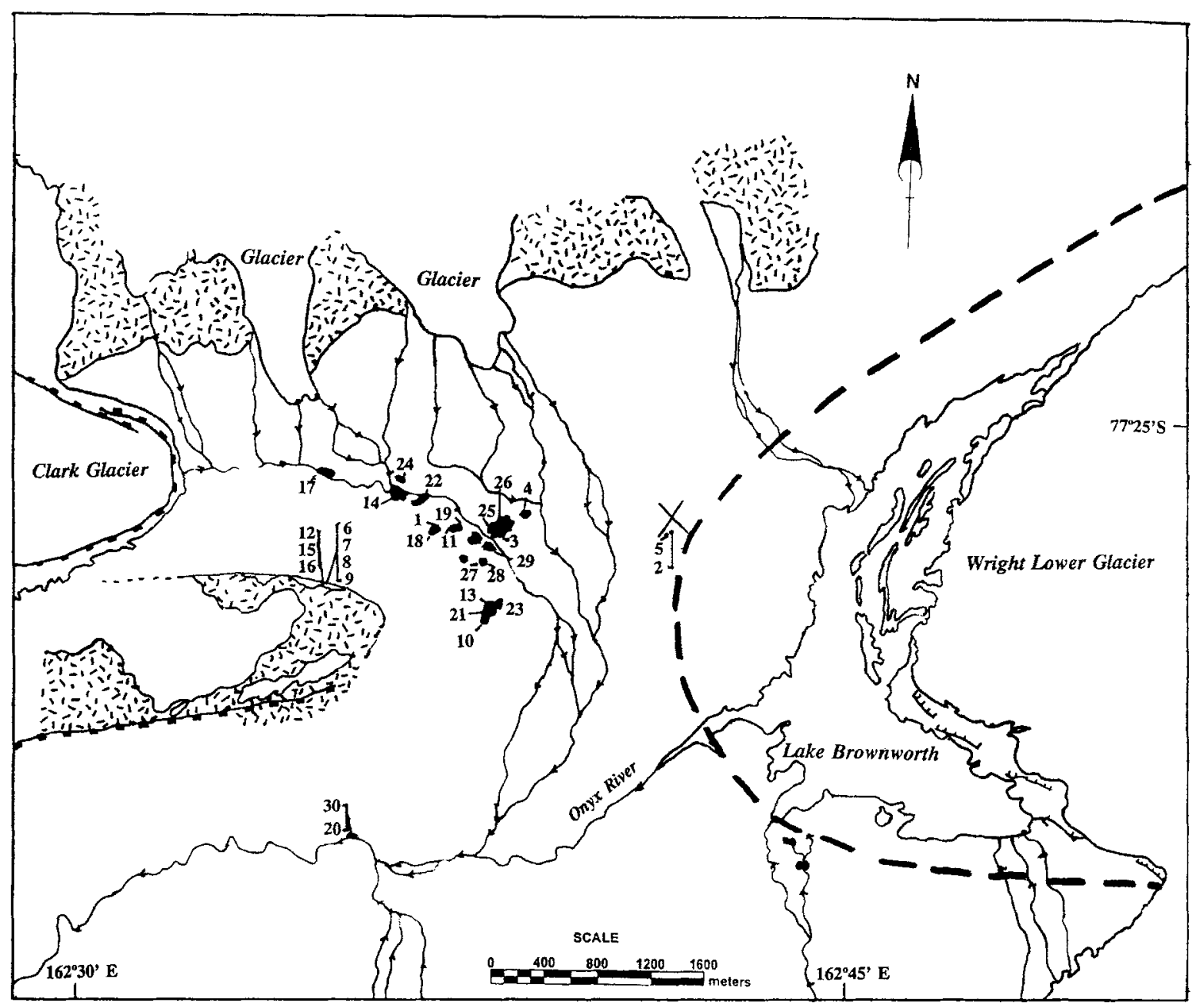

Fig. 2. Map showing location of deltas and shorelines in eastern Wright Valley. Numbered sites are keyed to Table I. The thick dashed line shows schematically the maximum possible LGM position of Wright Lower Glacier (the LGM position likely was well behind the maximum possible position), based on glacial geology which shows only glacial lacustrine features and not moraines, and on the presence of pre-LGM landforms that have not been overridden. The large X marks the general location of intact lacustrine deposits with infinite radiocarbon ages that were not overridden by glacier ice at the LGM. Deltas are shown in black. The shoreline is designated by a black line that is distinguished from other lines by its association with radiocarbon sites. Hatch-marks indicate bedrock exposures.

\section{Radiocarbon chronology}

Our radiocarbon chronology is based on 30 AMS dates of lacustrine algae that grew in Glacial Lake Wright (Table I). One potential problem is that the radiocarbon dates might require correction, due either to a marble hardwater effect or to the lack of aeration of lake water because of the perennial ice cover. Marble crops out locally in Wright Valley, but forms an insignificant proportion of bedrock. In addition, all but two of our samples come from deltas and shorelines deposited in the moat, which should have been well-aerated. Recent work by Doran et al. (1999) for Lake Fryxell in Taylor Valley showed that algae from present-day deltas yield modern ages. Therefore, we feel confident in our dates from deltas and shorelines. Two of our dates are from glaciolacustrine deposits, which would have been let down onto algae living on the lake floor at unknown, but probably shallow, depth because the algae require light. The lake-bottom residence effect may be widely varying and not enough data are present to make a reasonable correction to these dates (Hendy et al. 1977, Doran et al. 1999, Hendy 2000). Therefore, we do not attempt correction of dates of lake-bottom algae and note only that dates of glaciolacustrine deposits are consistent with those of deltas in that they show that Glacial Lake Wright existed during the LGM.

Radiocarbon dates of deltas range from $7355 \pm 62$ (AA13571) to $25697 \pm 245$ (AA-14048) ${ }^{14} \mathrm{C}$ yr BP and suggest the same surface-level oscillations seen in adjacent valleys (Hall $\&$ Denton 1998). The shoreline, which marks the highstand of Glacial Lake Wright, dates between $14544 \pm 124$ (AA14191) and $15399 \pm 113(\mathrm{AA}-18926){ }^{14} \mathrm{C}$ yr BP. One of the 


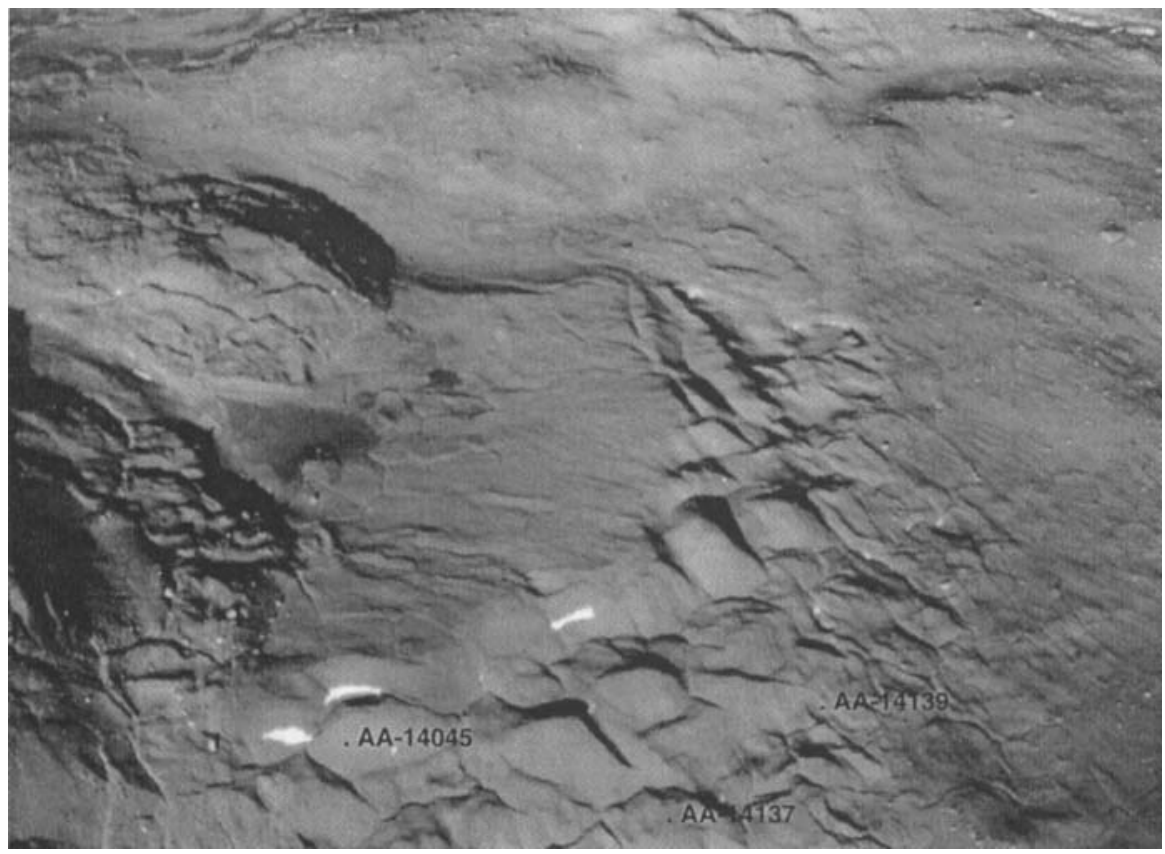

Fig. 3. Oblique aerial view of a delta adjacent to Clark Stream in eastern Wright Valley. This delta covers about $8000 \mathrm{~m}^{2}$ and has over $10 \mathrm{~m}$ of relief. Radiocarbon dates can be found in Table I. mounds on the shoreline has dates of $10855 \pm 90$ (AA-20656) and $10737 \pm 76(\mathrm{AA}-14051)$, indicating that lake level reached the 566-m shoreline on at least two occasions. We have been unable to replicate a third date from the same mound of $11983 \pm 87{ }^{14} \mathrm{C}$ yr BP (AA-18211) and believe it to be in error. Glaciolacustrine deposits date to $18736 \pm 145$ (AA-17336) and $20580 \pm 193$ (AA-18927) ${ }^{14} \mathrm{C} \mathrm{yr} \mathrm{BP}$ and fall within the same general time range as the deltas and shoreline. All of these dates indicate that Glacial Lake Wright existed during the LGM and early Holocene.

\section{Discussion}

Size of Glacial Lake Wright

Although most evidence for its existence comes from the eastern part of the valley, Glacial Lake Wright must have occupied all of Wright Valley, extending from the forks of the Dais to Wright Lower Glacier. This is because Wright Valley has intcrnal drainage. We reject the possibility that an ice dam, located somewhere between the central depression at Lake Vanda and our sites, caused formation of a local lake in eastern Wright Valley. Small alpine glaciers on the south

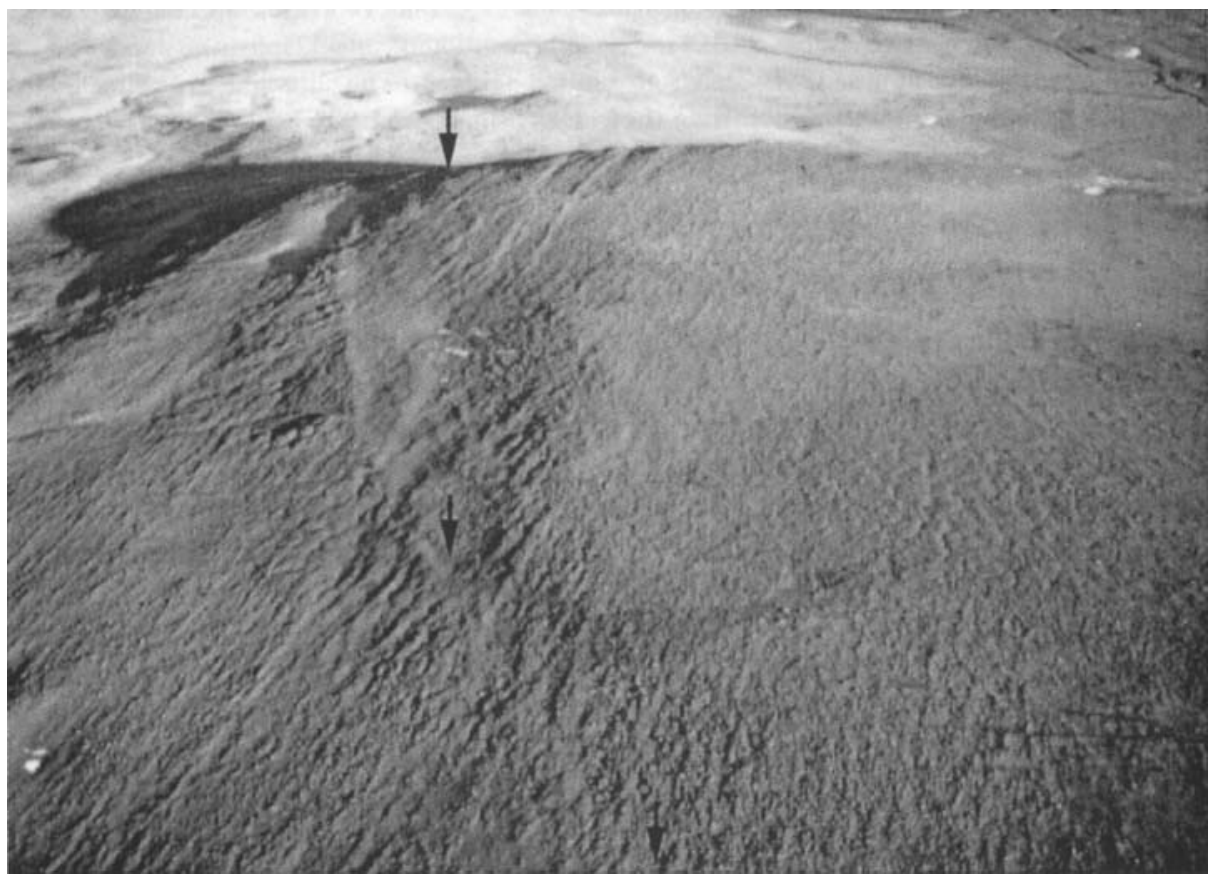

Fig. 4. Oblique aerial photograph of a shoreline preserved at $566 \mathrm{~m}$ elevation on the south-west wall of Clark Valley. View is to the southeast into Wright Valley. In the foreground, topography slopes down from right to left. The shoreline trends diagonally (top to bottom) in the left half of the photograph and is noted by arrows. Other linear features seen in the photograph have glacial and structural origins. 


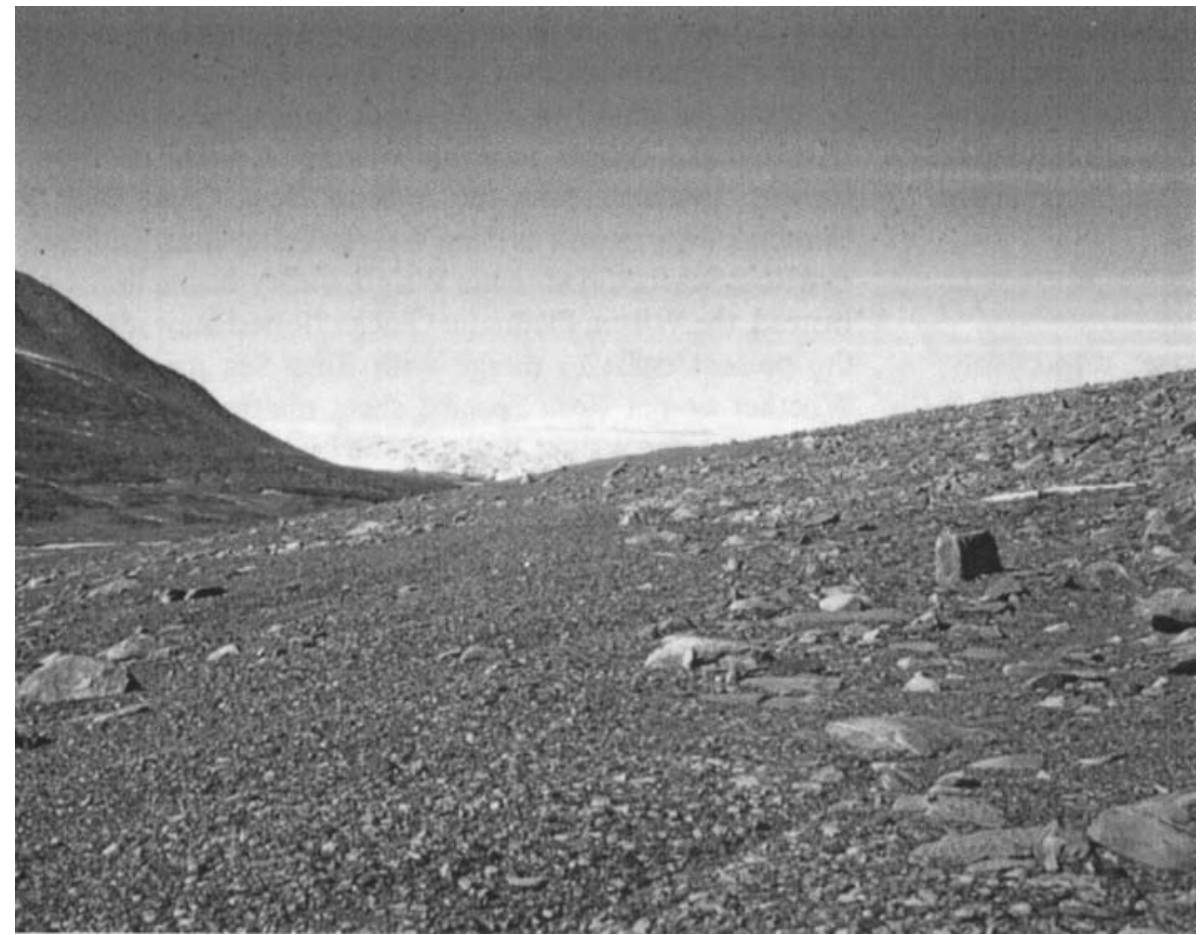

Fig. 5. Close-up photograph of the shoreline on the south-west wall of Clark Valley showing the contrast in grain size between the shoreline and the till upslope (right). The shoreline occupies the bottom-central portion of the photograph and can be identified by its finer grain size, as well as by other features noted in the text.

valley wall between eastern Wright Valley and Lake Vanda (Fig. 1) are constrained to within one kilometre of their present positions since at least $3.7 \mathrm{Ma}$ (Hall et al. 1993). They could not have blocked the valley. Likewise, Wright Upper Glacier has not flowed through Wright Valley and could not have dammed a lake since at least Pliocene time (Hall et al. 1993). In the eastern valley end, mapping of multiple drift sheets shows that Wright Lower Glacier has not been sufficiently thick nor extensive to dam a local lake in Clark Valley since at least early-to mid-Quaternary time (Hall \& Denton unpublished data and Fig. 2). Well-preserved (i.e. not overridden by ice) lacustrine deposits with infinite radiocarbon ages occur at low elevation within $1.5 \mathrm{~km}$ of present-day Wright Lower Glacier (Hall \& Denton unpublished data and Fig. 2). Therefore, LGM advance of Wright Lower Glacier is restricted to $<1.5 \mathrm{~km}$ (Clark Valley is over $3 \mathrm{~km}$ to the west and nearly $200 \mathrm{~m}$ higher in elevation than the snout of Wright Lower Glacier). Moreover, several of the deltas (including one along the Onyx River) are not actually in Clark Valley and could not have formed in any lake dammed by Wright Lower Glacier. Because of the internal drainage of Wright Valley and the fact that the deltas and shorelines could not have formed in an ice-dammed lateral lake, we believe that the lacustrine deposits dated to the LGM and early Holocene in eastern Wright Valley record the presence of a large proglacial lake that filled the entire valley. At its largest, the lake would have stretched $50 \mathrm{~km}$ and covered at least $210 \mathrm{~km}^{2}$, with a maximum depth of about $550 \mathrm{~m}$.

When Glacial Lake Wright was above $275 \mathrm{~m}$ elevation, it would have been proglacial to, and dammed by, Wright Lower Glacier or the Wilson Piedmont Glacier. The actual ice thickness required to dam the lake is highly dependent on the
Table I. Radiocarbon dates from lacustrine deposits in eastern Wright Valley. These dates are adjusted for $\delta^{13} \mathrm{C}$ variations but are otherwise uncorrected.

\begin{tabular}{cclrl}
\hline Sample & Lab. no. & ${ }^{14}$ C yr BP $(\mathrm{m})$ & Elev. & Deposit \\
\hline 1 & AA-14048 & $25697 \pm 245$ & 440 & delta \\
2 & AA-18927 & $20580 \pm 193$ & c. 330 & glaciolacustrine deposit \\
3 & AA-14139 & $19860 \pm 227$ & 415 & delta \\
4 & AA-14138 & $19021 \pm 151$ & 421 & delta \\
5 & AA-17336 & $18736 \pm 145$ & c. 330 & glaciolacustrine deposit \\
6 & AA-18926 & $15399 \pm 113$ & 566 & shoreline \\
7 & AA-17337 & $15050 \pm 111$ & 566 & shoreline \\
8 & AA-17299 & $14605 \pm 95$ & 566 & shoreline \\
9 & AA-14191 & $14544 \pm 124$ & 566 & shoreline \\
10 & UGA-6769 & $12715 \pm 80$ & 394 & delta \\
11 & AA-18896 & $12015 \pm 75$ & 437 & delta \\
12 & AA-18211 & $11983 \pm 87$ & 566 & repeat of AA-14051, \\
& & & & probably erroneous \\
13 & AA-18895 & $11630 \pm 72$ & 394 & delta \\
14 & AA-14043 & $11177 \pm 112$ & 450 & delta \\
15 & AA-20656 & $10855 \pm 90$ & 566 & shoreline mound same \\
& & & & mound as AA-14051 \\
16 & AA-14051 & $10737 \pm 76$ & 566 & shoreline mound \\
17 & AA-18893 & $10678 \pm 114$ & c. 460 & delta \\
18 & AA-18894 & $10566 \pm 85$ & 442 & delta \\
19 & AA-14046 & $10117 \pm 73$ & 431 & delta \\
20 & AA-18898 & $8619 \pm 66$ & c. 250 & delta \\
21 & AA-14044 & $8441 \pm 62$ & 394 & delta \\
22 & AA-14049 & $8411 \pm 76$ & 443 & delta \\
23 & AA-13579 & $8301 \pm 78$ & 387 & delta \\
24 & AA-14135 & $8300 \pm 68$ & 443 & delta \\
25 & AA-14137 & $8120 \pm 66$ & 420 & delta \\
26 & AA-14045 & $8117 \pm 107$ & 420 & delta \\
27 & AA-13580 & $8096 \pm 77$ & 419 & delta \\
28 & AA-14136 & $8053 \pm 86$ & 418 & delta \\
29 & AA-14047 & $7944 \pm 65$ & 421 & delta \\
30 & AA-13571 & $7355 \pm 62$ & c. 250 & delta \\
\hline & & & & \\
\hline
\end{tabular}


location of the grounding line and on subglacial topography, both of which are poorly constrained. Assuming the grounding line was at the topographic high beneath the Wilson Piedmont Glacier (270 m elevation; Calkin 1974), a rough minimum estimate of ice thickness at the grounding line can be calculated as follows:

$$
\rho_{\text {ice }} \mathbf{h}_{\text {ice }}=\rho_{\text {water }} \mathbf{h}_{\text {water }}
$$

where $\rho$ and $h$ are the densities and thicknesses, respectively, of ice and water. Given that the lake highstand was at $566 \mathrm{~m}$ elevation, $h_{\text {water }}$ at the grounding line would have been $296 \mathrm{~m}$ $(566 \mathrm{~m}-270 \mathrm{~m})$. Taking $\rho_{\text {ice }}$ to be 0.9 and $\rho_{\text {water }}$ to be 1.0 , we solve for the $h_{\text {ice }}$ needed to prevent ice at the grounding line from floating:

$$
(0.9) \mathrm{h}_{\text {ice }}=(1.0)(296 \mathrm{~m})
$$

Rearranging for $h_{\mathrm{sce}}$,

$$
h_{\text {ice }}=296 \mathrm{~m} / 0.9=328.9 \mathrm{~m}
$$

Therefore, approximately $330 \mathrm{~m}$ of ice would be needed at the grounding line to prevent floating. This leads to an ice-surface elevation of $330 \mathrm{~m}+270 \mathrm{~m}$ or $600 \mathrm{~m}$. Given that ice-surface elevations do not exceed $400 \mathrm{~m}$ at this location today, the Wilson Piedmont Glacier must have thickened a minimum of $200 \mathrm{~m}$ at the LGM, in order to dam Glacial Lake Wright. Greater ice thickness would be required if the grounding line were not located at the topographic high. Support for such a thickening comes from the Scott Coast opposite Wright Valley, wherc the Wilson Piedmont Glacier advanced during the LGM (Hall \& Denton 2000).

Although Glacial Lake Wright was significantly larger than any lake that exists in the McMurdo Dry Valleys today, it was of a size similar to that of a well-documented proglacial lake, Glacial Lake Washburn, that existed in adjacent Taylor Valley at the LGM and in the early Holocene (Péwè 1961, Stuiver et al. 1981, Denton et al. 1989, Hall et al. 2000). A large glacial lake (Glacial Lake Trowbridge) also formed at the LGM in Miers Valley in the foothills of the Royal Society Range (Péwè 1961, Clayton-Greene et al. 1988).

\section{Source of water for Glacial Lake Wright}

At its highest stand, Glacial Lake Wright contained approximately $60 \mathrm{~km}^{3}$ of water. The source of this water and the climate conditions which led to its formation are still under investigation (Hall \& Denton 1998). Today, over $95 \%$ of the water that enters Lake Vanda comes from Wright Lower Glacier (Chinn 1980). Contribution from small local alpine glaciers is minimal. It may have been even less at the LGM because the alpine glaciers were smaller than they are at present (Stuiver et al. 1981). Meltwater from Wright Upper Glacier is insignificant and does not reach beyond the Labyrinth. It is possible that it produced more meltwater during the LGM, but evidence for this in the form of channels leading to central Wright Valley is lacking. Therefore, most water that filled
Glacial Lake Wright likely came from Wright Lower Glacier and the Wilson Piedmont Glacier. The grounded ice sheet that occupied the Ross Sea Embayment during the existence of Glacial Lake Wright probably was not a direct meltwater source. Evidence from the adjacent Scott Coast (Hall \& Denton 2000), as well as from Wright Valley itself, indicates that Ross Sea ice did not enter Wright Valley during the LGM. Instead, the Wilson Piedmont Glacier flowed seaward across the present coast to merge with Ross Sea ice off-shore. Whether or not Ross Sea ice sheet meltwater could still somehow enter Wright Valley at the LGM through overflow of interlobate lakes is unknown. However, it is clear from glacial geologic evidence that the Ross Sea ice sheet was not sufficiently thick to contribute meltwater in any manner to Glacial Lake Wright in early Holocene time (Hall \& Denton 2000).

Lake Vanda is a closed-basin lake. Surface level fluctuations are caused by an imbalance between meltwater input from the Onyx River and sublimation from theice surface. Groundwater flow and precipitation onto the lake surface are negligible (Thompson 1973, Matsubaya et al. 1979, Green et al. 1988, Chinn 1993, Hendy 2000). Szesztay (1974) classified lakes according to the balance between inflow and outflow. Closedbasin lakes in the McMurdo Dry Valleys meet Szesztay's (1974) criteria of being controlled by a balance between runoff and evaporation (sublimation). According to StreetPerrott \& Harrison (1985), such lakes magnify even minor climate signals, and therefore are classified as amplifier lakes. Data gathered over the past 30 years suggest that Lake Vanda does respond rapidly to water imbalances (Chinn 1993).

Like Lake Vanda, Glacial Lake Wright also was an amplifier lake. In addition, because it would have been proglacial at its highest stands, the lake would have been susceptible to changes in water level due to fluctuations of Wright Lower Glacier. However, given the size and depth of Glacial Lake Wright relative to the size of Wright Lower Glacier, coupled with the fact that the glacier probably did not advance at the LGM, any variations in the position of Wright Lower Glacier are likely to have had only a minor effect on lake level.

Today, annual flow of the Onyx River at the Lake Vanda weir averages $2 \times 10^{6} \mathrm{~m}^{3}$ (Chinn 1981, 1993). Even under the present climate this average can vary up to a factor of 7.5 , with the level of Lake Vanda accordingly decreasing or increasing by as much as -0.20 and $+2.06 \mathrm{~m} \mathrm{yr}^{-1}$ (Chinn 1993). Ablation (30.5 mm year ${ }^{-1}$; Chinn \& McSaveney 1987) has remained constant over the past 20 years and changes in lake level likely are due to fluctuations in meltwater inflow (Chinn 1993). Low flow years are commonly characterized by snowy, cloudy conditions during the crucial melt season. In 1977-78, a single snow storm which brought $20 \mathrm{~cm}$ of snow in late October, halted melting for days and the Onyx River system never recovered to flow to Lake Vanda (Chinn 1993, personal observation). Based on our own observations, we believe that such late spring snow storms may be related to large amounts of open water in adjacent McMurdo Sound, as well as to 
cyclonic storms.

The origin of high-flow years is less straightforward. Chinn (1981, 1993) examined the unusually high-flow year of 1970-71 when $15 \times 10^{6} \mathrm{~m}^{3}$ of water flowed into Lake Vanda. He noted that climate conditions did not show any unusual pattern. If anything, the summer was slightly cooler than normal. Overall, Chinn (1993) noted poor (if not nonexistent) correlation between lake-level changes in the McMurdo Dry Valleys over the past three decades and temperature records at Vanda station. This was attributed in part to the fact that Lake Vanda receives most of its water from the Wilson Piedmont Glacier on the coast in a different climate regime from Vanda station, as well as to inherent difficulties in obtaining good correlation among records in different valleys (Chinn 1993). However, Chinn (1993) also noted that lakes farther north in the Convoy Range and in the Terra Nova Bay region appeared to be falling during intervals of warm temperature, because of increased snowfall. This work supported and expanded on an earlier hypothesis used to explain the existence of Glacial Lake Washburn in Taylor Valley (Denton et al . 1989). Other researchers have proposed alternate mechanisms, such as an increase in precipitation (Wilson 1970) or temperature (Smith \& Friedman 1993). The hypothesis of expanding lake size due to an increase in precipitation does not seem to be supported by observational data (Chinn 1993, Fountain et al. 1999). Temperature variations may play a role, but based on recent data (Chinn 1993, Fountain et al. 1999, personal observations) it seems to us that radiation balance related to snow cover is more critical. Moreover, it is difficult from a palaeoclimate perspective to argue that the McMurdo Dry Valleys were actually warmer at the LGM than they are now, particularly when the adjacent Taylor Dome ice core shows that the region was colder (Steig et al. 1998).

Building on the suggestion of Denton et al. (1989) and the observations of Chinn (1993), Hall \& Denton (1996) proposed that meltwater production in the McMurdo Dry Valleys responds not so much to temperature (although it may play a role), but to radiation balance. In this regard, melting would be favoured on sunny, clear days in summers when snowfall (which causes a high albedo) is rare. In contrast, snowy, cloudy conditions, perhaps brought on by warmer temperatures which would cause an earlier than usual breakout of sea ice, would inhibit meltwater production. Fountain et al. (1998) and Hendy (2000) independently made observations that suggested that a significant (but unquantified) portion of meltwater forms just below the surface of the glacier by absorption of solar radiation along crystal boundaries to a depth of about one metre. This process can take place even at temperatures below $0^{\circ} \mathrm{C}$. The meltwater produced by this process eventually coalesces to form small rivulets and streams that flow beneath a surface crust to the edge of the glacier, where they cascade over the cliff (typically $20 \mathrm{~m}$ high). This melt process is favoured by clear, cloudless, snowless days. Even a thin coating of snow on the glacier surface halts melting.

Hall \& Denton (1996) suggested that somewhat cooler, but drier and sunnier conditions during the LGM and early Holocene would have led to higher lake levels. Drier conditions most likely would have occurred because distance to open water was increased dramatically by the presence of an ice sheet in the Ross Sea Embayment and extensive fringing sea ice. Support for cold, dry conditions during lake highstands at $10700{ }^{14} \mathrm{Cyr} \mathrm{BP}$ and during the LGM comes from the nearby Taylor Dome ice core (Steig et al. 1998). Drier conditions also are indicated by the retreat of alpine glaciers in the Dry Valleys during glacial periods (Dort 1970, Stuiver et al. 1981, Hall et al. 1993).

Drier conditions might at first appear to conflict with suggestions made above that the Wilson Piedmont Glacier thickened at the LGM. This thickening is required by the surface elevation of Glacial Lake Wright, as well as by moraines found along the Scott Coast that show LGM expansion of the piedmont glacier (Hall \& Denton 2000). We cannot yet give a definitive solution to this apparent conflict with the available data, but we offer the following hypothesis. At present, a major source of ablation for the Wilson Piedmont Glacier is calving into the Bay of Sails, as attested to by the large number of icebergs present. At the LGM, the coastal margin of the piedmont glacier was buttressed by the grounded Ross Sea ice sheet (Hall \& Denton 2000). Calving was eliminated, which would have caused thickening of the piedmont glacier. It is also possible that the divide of the Wilson Piedmont Glacier shifted eastward in response to this significant decrease in ablation on the coastal side and concurrent decrease in precipitation on the inland margin. If such a shift occurred, it would have yielded a larger catchment area for the Onyx River and diverted many of the streams on the glacier surface from the coast to Wright Valley.

Recently, Hall \& Denton (1998) noted that lake levels in Wright Valley, as well as in adjacent Taylor and Victoria Valleys, did not remain constant at the LGM, but rather fluctuated, perhaps with a millennial pulsebeat. The details and mechanics of these fluctuations currently are being assessed and will be the subject of a separate paper. However, fluctuations in the level of Glacial Lake Wright someday may be used to extract a record of high frequency climate change from terrestrial Antarctica.

\section{Conclusions}

1) A large proglacial lake, Glacial Lake Wright (c. $210 \mathrm{~km}^{2}$ ), filled Wright Valley at the LGM and in the early Holocene. Chronological control is from dates of lacustrine algae preserved in deltas, shorelines, and glaciolacustrine deposits.

2) The Wilson Piedmont Glacier must have thickened by at least $200 \mathrm{~m}$ at the LGM in order to dam Glacial Lake Wright at its highest stands. 
3) The source of water for Glacial Lake Wright was likely the Wilson Piedmont Glacier and/or Wright Lower Glacier.

4) The climate conditions which led to the formation of Glacial Lake Wright are still under investigation; however, the environment is believed to have been cold, dry, sunny, and snowless, which would have promoted greater absorption of solar radiation and hence greater meltwater production.

\section{Acknowledgements}

R. Verow assisted in the field. C. Hendy and T. Chinn provided valuable insight into the structure and hydrology of Antarctic lakes. We thank T. Chinn, R. Powell, and an anonymous reviewer for their comments. Radiocarbon dates were processed at the NSF-Arizona AMS facility. This research was supported by the Office of Polar Programs of the National Science Foundation. The paper was written while the first author was supported by a USGS Postdoctoral Scholarship at Woods Hole Oceanographic Institution.

\section{References}

CALKIN, P.E. 1974. Subglacial geomorphology surrounding the icefree valleys of southern Victoria Land, Antarctica. Journal of Glaciology, 13, 415-429.

CHIN, T.J.H. 1979. Impact of extreme events on the dry valleys area. New Zealand Antarctic Record, 2, 9-13.

Chin, T.J.H. 1980. Hydrological research report, Dry Valleys, Antarctica, 1970-71. Christchurch: New Zealand Ministry of Public Works, $45 \mathrm{pp}$.

Chin, T.J.H. 1981. Hydrology and climate in the Ross Sea area. Journal of the Royal Society of New Zealand, 11, 373-386.

Chrn, T.J.H. 1993. Physical hydrology of the Dry Valleys lakes. Antarctic Research Series, 59, 1-51

Chinn, T.J.H. \& MCSAveney, M.J. 1987. On the flooding of Vanda station. New Zealand Antarctic Record, 7, 23-31.

Clayton-Greene, J.M., Hendy, C.H. \& Hogg, A.G. 1988. The chronology of a Wisconsin-aged proglacial lake in the Miers Valley, Antarctica. New Zealand Journal of Geology and Geophysics, 31, 353-361.

Denton, G.H., Bockheim, J.G., Wilson, S.C. \& Stuiver, M. 1989. Late Wisconsin and early Holocene glacial history, inner Ross Embayment, Antarctica. Quaternary Research, 31, 151-182.

Doran, P.T., Berger, G.W., Lyons, W.B., Wharton JR, R.A., Davisson, M.L., Southon, J. \& DiBb, J.E. 1999. Dating Quaternary lacustrine sediments in the McMurdo Dry Valleys, Antaretica. Palaeogeography, Palaeoclimatology. Palaeoecology, 147, 223-239.

DORT, W. 1970. Climatic causes of alpine glacier fluctuation, southern Victoria Land. International Symposium on Antarctic Glaciological Exploration. International Association of Scientific Hydrology and $S C A R, 86,358-362$.

Fountain, A.G., Dana, G.L., Lewis, K.J., Vaugh, B.H. \& McKnight, D. 1998. Glaciers of the McMurdo Dry Valleys, southern Victoria Land, Antarctica. Antarctic Research Series, 72, 65-75.
Fountain, A.G., Lyons, W. B., Burkins, M. B., Dana, G.L., Doran, P.T., Lewis, K.J., McKnight, D.M, Moorhead, D.L., Parsons, A.N., Priscu, J.C., Wall, D.H., Wharton JR, R.A. \& Virginia, R.A. 1999. Physical controls on the Taylor Valley ecosystem, Antarctica. Bioscience, 49, 961-971.

Green, W.J., Angle, M.P. \& Chave, K.E. 1988. The geochemistry of Antarctic streams and their role in the evolution of four lakes in the McMurdo Dry Valleys. Geochimica et Cosmochimica Acta, 52, $1265-1274$

Hall, B.L. \& Denton, G.H. 1996. Deglacial chronology of the western Ross Sea. Antarctic Journal of the United States, 31(2), 78-80.

Hall, B.L. \& Denton, G.H. 1998. Millennial-scale fluctuations of Antarctic lakes. Abstracts with Programs, AGU Chapman Conference, Mechanisms of Millennial-Scale Climate Change, Snowbird, Utah, 19

Hall, B.L. \& Denton, G.H. 2000. Extent of the Wilson Piedmont Glacier and the Ross Sea ice sheet along the Scott Coast at and since the last glacial maximum. Geografiska Annaler, 82A, 337-363.

Hall, B.L., Denton, G.H. \& Hendy, C.H. 2000. Evidence from Taylor Valley for a grounded ice sheet in the Ross Sea Embayment Geografiska Annaler, 82A, 275-303.

Hall, B.L., Denton, G.H., Lux, D.L. \& Bockheim, J.G. 1993. Late Tertiary paleoclimate and ice-sheet dynamics from surficial deposits in Wright Valley. Geografiska Annaler, 75A, 239-268.

Hendy, C.H. 2000. Late Quaternary lakes in the McMurdo Sound region of Antarctica. Geografiska Annaler, 82A, 411-432.

Hendy, C.H., Wilson, A.T., Popplewell, K.B. \& House, D.A. 1977. Dating of geochemical events in Lake Bonney, Antarctica, and their relation to glacial and climate changes. New Zealand Journal of Geology and Geophysics, 20, 1103-1122

Matsubaya, O., Sakai, H., Torit, T., Burton, H. \& Kerry, K. 1979 Antarctic saline lakes - stable isotope ratios, chemical compositions, and evolution. Geochimica et Cosmochimica Acta, 41, 7-25.

PÉwé, T. 1961. Multiple glaciations in McMurdo Sound region, Antarctica - a progress report. Geology, 68, 498-514.

RIordan, A.J. 1973. The climate of Vanda Station, Antarctica. In RAASCH, G.O., ed. Geology of the Arctic. Toronto: University of Toronto Press, 268-275.

Smith, G.I. \& FrIedman, I. 1993. Lithology and paleoclimate implications of lacustrine deposits around Lake Vanda and Don Juan Pond, Antarctica. Antarctic Research Series, 7, 83-94.

Steig, E.J., Brook, E.J., White, J.W.C., Sucher, C.M., Bender, M.L., Lehman, S.J., Morse, D.L., Waddington, E.D. \& Clow, G.D. 1998. Synchronous climate changes in Antarctica and the North Atlantic. Science, 282, 92-95.

Stuiver, M., Denton, G.H., Hughes, T.J. \& Fastook, J.L. 1981. History of the marine ice sheet in West Antarctica during the last glaciation, a working hypothesis. In Denton, G.H. \& Hughes, T.J., eds. The last great ice sheets. New York: Wiley Interscience, $319-436$.

Street-Perrott, F.A. \& Harrison, S.P. 1985. Lake levels and climate reconstruction. In HECHT, A.D., ed. Paleoclimate analysis and modeling. New York: John Wiley, 291-340.

Szesztay, K. 1974. Water balance and water level fluctuations of lakes. Hydrological Sciences Bulletin, 19, 73-84.

Thompson, D.C. 1973. Climate of the Dry Valleys area of southern Victoria Land. New Zealand Geographical Society Conference Series, 4, 259-265.

Wilson, A.T. 1970. The McMurdo Dry Valleys. In Holdgate, M.W., ed. Antarctic ecology, vol. I. London: Academic Press, 21-30 